76 巻 763 号 $(2010-3)$

\title{
ピストン・コンロッド系の動力学とクランク軸のねじれ振動の 連成を考慮したエンジンの振動解析*
}

河口篤志*1, 川本敦史*1, 青山隆之*2 黒石 真 且*1, 稲 垣 瑞 穂*1

\section{Engine Vibration Analysis with Coupling Between Piston-Connecting-Rod Dynamics and Crankshaft Torsional Vibration}

Atsushi KAWAGUCHI*3 ${ }^{*}$, Atsushi KAWAMOTO, Takayuki AOYAMA, Masakatsu KUROISHI and Mizuho INAGAKI

*3 Toyota Central R \& D Labs., Inc., 41-1 Yokomichi, Nagakute-cho, Aichi-gun, Aichi, 480-1192 Japan

This paper deals with computer-based simulation techniques on automobile engine vibrations. In the previous study, we developed an in-house software package called EVAS (Engine Vibration Analysis System) for predicting engine vibrations under running condition. EVAS is a flexible multibody dynamics solver that can comprehensively analyze the coupled phenomena by using its predefined body elements and several types of force elements which express mechanical joints such as journal bearings. In this paper, in order to calculate crankshaft torsional vibrations more accurately and efficiently, we propose a new force element of piston-connecting-rod sub-system considering the dynamic effects induced by the elastic deformation of the crankshaft. The new force element is applied to an in-line 4-cylinder engine model and its effectiveness is discussed compared with the experimental results. Then, using the element, we also investigate the vibration transmitting mechanism from the torsional and bending vibrations of the crankshaft to the elastic vibrations of cylinder-block through the bearing dynamics forces.

Key Words: Automobile Engine, Vibration, Flexible Multibody Dynamics, Crankshaft Torsional Vibration, Piston-Connecting-Rod System, Computer Aided Engineering

\section{1. 緒 言}

近年の自動車用エンジンには，低燃費化のため，よ り一層の部品の軽量化や軸受の細径化による低剛性化 などが要求されており，それらと背反する振動騒音の 低減設計技術が益々重要となっている，多くの部品で 構成されるエンジンの振動騒音を，より效率的に対策 するためには，部品間の相互作用を考慮して，実働時 の動的挙動を正確に予測できる計算法が必要である。

従来のエンジン振動予測に関する研究は, 高周波数 域(1 kHz 以上)の微小弾性振動を対象とするも $の^{(1) \sim(5)}$, もしくは低周波数域(数十 $\mathrm{Hz}$ 以下)の機構運 動を対象とするもの ${ }^{(6)(7)}$ に分類される。しかし，実際 のエンジン設計に扔いては, 機構運動と弾性振動が連 成する中間の周波数域（数十～数百 $\mathrm{Hz}$ ) を含め, 全周 波数域に対応できる振動予測技術が必要とされる.

筆者らはこれまでに, 機構運動と弾性振動の連成問 題をより効率的に計算する解析手法を提案し ${ }^{(8)}$,すべ り軸受などの各種機械ジョイントの動特性も考慮し

* 原稿受付 2009 年 10 月 1 日.

*1 正負, (株) 豊田中央研究所 (画 480-1192 愛知罢愛知郡長久 手町大字長湫字横道 41-1).

*2 (株) 豊田中央研究所.

E-mail : kawaguchi@mosk.tytlabs.co.jp
て, エンジンの運動・振動現象を広周波数域で解析で きるCAE システム(以下, EVAS : Engine Vibration Analysis System) 偓開してきた ${ }^{(9) \sim(12)}$.

前報 ${ }^{(8)}$ までの手法では，エンジン全体モデルの計算 自由度を減らすために，ピストン・コンロッド系の機 構を一般化自由度(物体要素)では表現せず，予めその 運動を仮定してその系に発生する力を計算する力要素 を導入している。しかしながら，クランク軸のねじれ 振動が大きくなるような場合には，クランク軸とピス トン・コンロッド系の動的な相互作用が発生し, 運動 を仮定している従来の力要素では，クランク軸のねじ れ振動が正確に予測できないことがある。

そこで本報では，クランク軸のねじれ振動の計算精 度改善を目的として，ピストン・コンロッド系とクラ ンク軸との動的な相互作用を考慮できる新たな力要素 を定式化し, 值列 4 気筒エンジンを対象にその有効性 を検証する。また，開発した力要素を用いて，クラン ク軸のねじれ・曲げ振動からシリンダブロック振動へ の振動伝達メカニズムを解明する。

\section{EVAS 計算手法の概要}

図 1 に示す直列 4 気筒エンジンを例に EVAS の計 算手法を概説する. EVASのモデルは図 2 に示すよ 
うに構成され，構成部品の運動・振動を表現する物体 要素と, 部品間の伝達力を表現する力要素で構成され る.図 2 のモデルでは，クランク軸とシリンダブロッ ク系(ミッションケースやオイルパンなどのケース系 を含む)を物体要素で表す。また，力要素は，その機能 に応じて, ピストン・コンロッド要素, すべり軸受要 素 (ジャーナル軸受), スラスト軸受要素, マウント要 素, ベルト要素, モータ要素(動力計を表す)に分類さ れる。図 2 中の\#忟氛筒番，“は軸受番号を表方。

$2 \cdot 1$ 物体要素の運動方程式 物体要素の振動特 性は, 有限要素モデルの固有モード解析によって得ら れたモーダルパラメータ(固有振動数, 固有モード)で 表す. EVASでは，常に物体要素の近傍に位置する局 所観測座標系を導入し，その座標系上で物体要素の剛 体運動と弾性振動を固有モードの重ね合わせで表す.

運動方程式は，次式のようにモード座標 $q_{k}$ を一般 化座標とする常微分方程式で表される(8) (10).

$$
\begin{aligned}
& m_{k} \ddot{q}_{k}+c_{k} \dot{q}_{k}+\sum_{i=1}^{N} M_{i} \boldsymbol{\phi}_{i k}^{\prime T} \boldsymbol{A}^{T} \ddot{\boldsymbol{r}} \\
& \quad+\sum_{i=1}^{N} M_{i} \boldsymbol{\phi}_{i k}^{\prime T} \boldsymbol{A}^{T}(\dot{\overline{\boldsymbol{\omega}}}+\tilde{\boldsymbol{\omega}} \tilde{\boldsymbol{\omega}}) \boldsymbol{A}\left(s^{\prime i}+\boldsymbol{\Phi}_{i}^{\prime} q\right)
\end{aligned}
$$

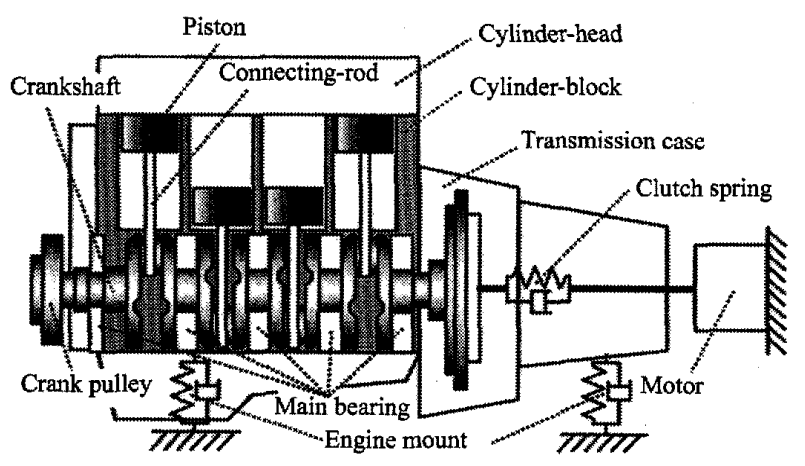

Fig. 1 In-line 4-cylinder engine

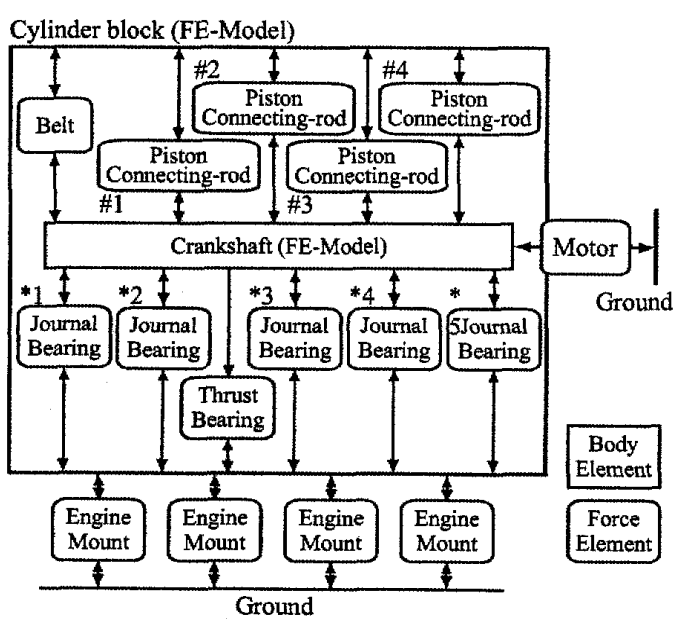

Fig. 2 Schematic of engine vibration analysis system

$$
\begin{aligned}
& +2 \sum_{i=1}^{N} M_{i} \boldsymbol{\phi}_{i k}^{\prime T} \boldsymbol{A}^{T} \tilde{\boldsymbol{\omega}} \boldsymbol{A} \boldsymbol{\Phi}_{i}^{\prime} \dot{q}_{k}+\lambda_{k} q_{k} \\
& =\sum_{i=1}^{N} \boldsymbol{\phi}_{i \hbar}^{\prime T} \boldsymbol{A}^{T} \boldsymbol{F}_{i} \ldots \ldots \ldots \ldots \ldots \ldots \ldots \ldots \ldots \ldots \ldots \ldots \ldots \ldots
\end{aligned}
$$

ここで, $\boldsymbol{\Phi}_{i}^{\prime}=\left[\boldsymbol{\phi}_{i 1}, \boldsymbol{\phi}_{i 2}, \cdots, \boldsymbol{\phi}_{i N}\right], q=\left[q_{1}, q_{2}, \cdots, q_{N}\right]$ であり， $m_{k} ， c_{k}, \lambda_{k}, q_{k}$ はそれぞれ， $k$ 次のモーダル 質量, 減衰係数, 剛性(固有值)，変位を表す。また， $\boldsymbol{\phi}_{i k}^{\prime}$ は $i$ 節点の $k$ 次のモードベクトル, $\boldsymbol{A}$ は方向余弦 マトリクス, $\dot{\boldsymbol{r}}$ は全体座標系から見た局所観測座標系 の加速度ベクトル， $\omega$ は局所観測座標系の角速度べク

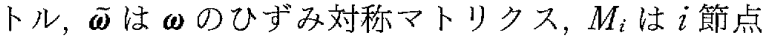
の質量, $\boldsymbol{F}_{i}$ は $i$ 節点に衝く力要素の力を表す.

左辺の第 3 5 項はそれぞれ，局所観測座標系の運 動による慣性力，コリオリ力，遠心力を表す。なお， 運動方程式の導出と局所観測座標系の設定 - 更新方法 は既報(8)を参照されたい。

$2 \cdot 2$ 力要素の定式化 力要素は, その機能に忘 じて, 結合する物体要素の状態量 (変位・速度など) か ら，物体要素に作用する力を計算する。ここでは，本 報の主題であるピストン・コンロッド系の力要素につ いて，予めピストン・コンロッド系の運動を仮定した 前報 ${ }^{(9)}$ の定式化を再揭する。

図 3 に示すピストン・コンロッド系の力要素は, ク ランク軸の回転角 $\theta$ の関数として, 燃焼ガスの爆発力 $F_{c}$ ，ピストンの側圧力 $F_{s}$ ，ピストン摩擦力 $F_{f}$, クラ ンクピン荷重 $F_{2 x}, F_{2 y}$ を計算する.

燃焼ガスの爆発力 $F_{c}$ 注，気筒内の直径 $D$ と気筒内 圧力 $p_{c}$ から, 次式で求められる.

$$
F_{c}=p_{c} \frac{\pi D^{2}}{4}
$$

スライダ・クランク機構の一般的な機構学の式か ら, ピストン変位 $s$ をランク軸の回転角 $\theta$ の関数と

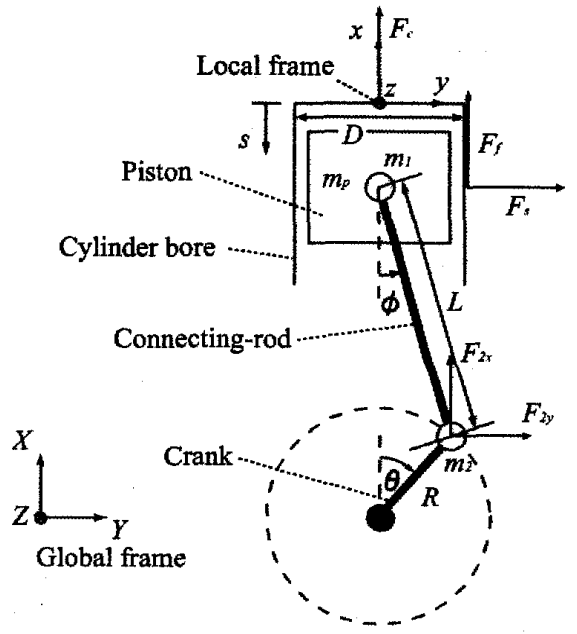

Fig. 3 Force element of piston-connecting-rod subsystem in previous version 
して, 次式で得られる.

$$
s=R\left[1-\cos \theta+\frac{\lambda}{4}(1-\cos 2 \theta)\right]
$$

ここで, $\lambda$ は連かん比 $(=R / L), R$ はクランク軸の回 転半径, $L$ はコンロッド長さである.

式 (3)を微分すると, ピストン速度, 加速度が以下 の上うに得られる。

$$
\begin{aligned}
& \dot{s}=R \dot{\theta}\left(\sin \theta+\frac{\lambda}{2} \sin 2 \theta\right) \\
& \ddot{s}=R \dot{\theta}^{2}(\cos \theta+\lambda \cos 2 \theta)
\end{aligned}
$$

次に，ピストン質量を $m_{p}$, コンロッド小端部の等 価質量を $m_{1}$ とし, 上記のピストン加速度 $\ddot{s}$ と燃焼ガ スの爆発力 $F_{c}$ を用いて, ピストン側圧力 $F_{s}$ を

$$
F_{s}=-\left[F_{c}-\left(m_{p}+m_{1}\right) \ddot{s}\right] \tan \phi
$$

と仮定する．またピストン側圧力 $F_{s}$ を抗力とするピ ストン摩擦力 $F_{f}$ を, 摩擦㲭数 $\mu$ として

$$
F_{f}=-\mu\left|F_{s}\right| \operatorname{sgn}\left(\dot{x}_{1}\right)
$$

と計算する. クランクピン荷重 $F_{2 x}, F_{2 y}$ は, コンロ ッド大端部の等価質量 $m_{2}$ を用いて,

$$
F_{2 x}=F_{c}+F_{f}+\left(m_{p}+m_{1}\right) \ddot{s}+m_{2} R \dot{\theta}^{2} \cos \theta
$$

$$
F_{2 y}=\left[F_{c}-F_{f}-\left(m_{p}+m_{1}\right) \ddot{s}\right] \tan \theta
$$$$
+m_{2} R \dot{\theta}^{2} \sin \theta
$$

と計算する.

\section{$2 \cdot 3$ ピストン・コンロッド要素の課題 式 (3)}

のように, 前報の定式化では, ピストン・コンロッド 系の運動をクランク軸の回転角 $\theta$ の関数として表し ている。このとき,クランク軸の回転半径 $R$ は一定 とし, 全気筒に共通の值を用いるが, 実際には, クラ ンク軸の弾性変形により, 回転半径 $R$ は気筒毎に変 化する。また,クランク軸の回転角 $\theta$ は, クランク軸 の剛体運動のみを考虑して算出し, 全気筒に共通の値 を用いる.しかし，実際には，クランク軸の㸚じれ変 形により各気筒のクランクピンの位置が変位するた め, クランクピンの位相角を表す各気筒の回転角 $\theta$ に は, ねじれ変形分の $\Delta \theta$ が加算されることになる.

この上うに, 前報の力要素では, クランク軸の弾性 変形に上る各気筒の回転半径 $R$ や回転角 $\theta$ の変動が 考慮されていないため, クランク軸の弾性変形が小さ い場合には問題ないが, 共振などでクランク軸のねじ れ振動が大きくなる場合には, ピストン・コンロッド 系とクランク軸の間の相互作用が正しく計算できない ことがある。

そこで本報では, クランク軸の弾性変形による気筒 ごとの回転半径 $R$ と回転角 $\theta$ の変化を考慮できるピ ストン・コンロッド系の新たな力要素を定式化する.
次章にその手法を示す。

\section{3. ピストン・コンロッド系の新力要素}

図 4 に新力要索のモデルを示す. 新力要素では，コ ンロッドの質量 $m_{c}$ を重心に集中し, 慣性モーメント $J_{c}$ を考慮する。

$3 \cdot 1$ 運動の定式化 要素座標系 $(x, y, z)$ はシリ ンダボアの上端に固定する。要素座標系の $z$ 軸は紙 面に垂直で, 紙面表面から奥に向かう向きを正方向と する.

図 4 亿示すように, 全体座標系 $(X, Y, Z)$ からみ た要素座標系の位置ベクトルを $\boldsymbol{c}$, ピストンピン位置 ベクトルを $\boldsymbol{r}_{1}$, クランクピン位置ベクトルを $\boldsymbol{r}_{2}$, コン ロッド重心位置ベクトルを $\boldsymbol{r}_{3}$ とする. また, 要素座 標系上でのピストンピン位置を $\left(x_{1}, y_{1}\right)$, クランクピ ン位置を $\left(x_{2}, y_{2}\right)$, コンロッド重心位置を $\left(x_{3}, y_{3}\right)$ とす る.また, $\hat{x}, \hat{y}$ は全体座標系からみた要甞座標系の 単位ベクトルである。

ピストンの中心点は常に要素座標系の $\hat{x}$ 軸(ボア中 心軸)に固定されているとして，

$$
y_{1}=0
$$

とする。また，コンロッド長さ $L$ は定とすると，

$$
\left(x_{1}-x_{2}\right)^{2}+\left(y_{1}-y_{2}\right)^{2}-L^{2}=0
$$

となる. 式( 8$),$ 式(9)より, 要素座標系上でのピス トンの变位・速度・加速度は

$$
\begin{aligned}
x_{1} & =\sqrt{L^{2}-y_{2}^{2}}+x_{2} \ldots \ldots \ldots \ldots \ldots \ldots \ldots \ldots \ldots \\
\dot{x}_{1} & =-\left(L^{2}-y_{2}^{2}\right)^{-1 / 2} y_{2} \dot{y}_{2}+\dot{x}_{2} \ldots \ldots \ldots \ldots \ldots \ldots \\
\ddot{x}_{1} & =-\left(L^{2}-y_{2}^{2}\right)^{-3 / 2} y_{2}^{2} \dot{y}_{2}^{2}-\left(L^{2}-y_{2}^{2}\right)^{-1 / 2} \dot{y}_{2}^{2} \\
& -\left(L^{2}-y_{2}^{2}\right)^{-1 / 2} y_{2} \ddot{y}_{2}+\ddot{x}_{2}
\end{aligned}
$$

となる.

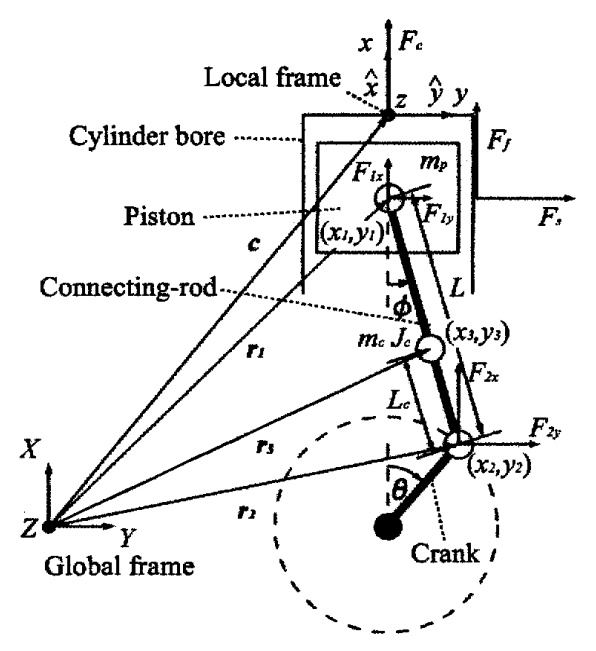

Fig. 4 Force element of piston-connecting-rod subsystem in improved version 
一方, 全体座標系上でのピストン位置・速度・加速 度ベクトルは,

$$
\begin{aligned}
& \boldsymbol{r}_{1}=\boldsymbol{c}+x_{1} \widehat{\boldsymbol{x}} \\
& \dot{\boldsymbol{r}}_{1}=\dot{\boldsymbol{c}}+\dot{x}_{1} \widehat{\boldsymbol{x}}+x_{1} \dot{\boldsymbol{x}} \cdots \ldots \ldots \ldots \ldots \ldots \ldots \ldots \ldots \ldots \ldots \\
& \dot{\boldsymbol{r}}_{1}=\ddot{\boldsymbol{c}}+\ddot{x}_{1} \widehat{\boldsymbol{x}}+2 \dot{x}_{1} \dot{\hat{\boldsymbol{x}}}+x_{1} \ddot{\overrightarrow{\boldsymbol{x}}}
\end{aligned}
$$

と表される。

同様に全体座標系上でのクランクピンの位置・速 度・加速度ベクトルは，

$$
\begin{aligned}
& \boldsymbol{r}_{2}=\boldsymbol{c}+x_{2} \hat{\boldsymbol{x}}+y_{2} \hat{\boldsymbol{y}} \\
& \dot{\boldsymbol{r}}_{2}=\dot{\boldsymbol{c}}+\dot{x}_{2} \hat{\boldsymbol{x}}+x_{2} \dot{\hat{\boldsymbol{x}}}+\dot{y}_{2} \hat{\boldsymbol{y}}+y_{2} \dot{\hat{\boldsymbol{y}}} \\
& \ddot{\boldsymbol{r}}_{2}=\ddot{\boldsymbol{c}}+\ddot{x}_{2} \widehat{\boldsymbol{x}}+2 \dot{x}_{2} \dot{\hat{\boldsymbol{x}}}+x_{2} \ddot{\ddot{\boldsymbol{x}}}+\ddot{y}_{2} \widehat{\boldsymbol{y}}+2 \dot{y}_{2} \dot{\hat{\boldsymbol{y}}}+y_{2} \ddot{\hat{\boldsymbol{y}}}
\end{aligned}
$$

と表される。

ここで, 式(12)の左から $\widehat{x}^{T}$ および $\widehat{\boldsymbol{y}}^{T}$ をかけ整 理すると, 要素座標系上でのクランクピン位置・速 度・加速度は次式で表される。

$$
\begin{aligned}
& x_{2}=\widehat{x}^{T}\left(r^{2}-c\right) \\
& y_{2}=\widehat{\boldsymbol{y}}^{T}\left(\boldsymbol{r}_{2}-\boldsymbol{c}\right) \\
& \dot{x}_{2}=\widehat{\boldsymbol{x}}^{T}\left(\dot{\boldsymbol{r}}_{2}-\dot{\boldsymbol{c}}-x_{2} \dot{\hat{\boldsymbol{x}}}-y_{2} \dot{\hat{\boldsymbol{y}}}\right) \\
& \dot{y}_{2}=\widehat{\boldsymbol{y}}^{T}\left(\dot{\boldsymbol{r}}_{2}-\dot{\boldsymbol{c}}-x_{2} \dot{\hat{\boldsymbol{x}}}-y_{2} \dot{\hat{\boldsymbol{y}}}\right) \\
& \ddot{x}_{2}=\widehat{\boldsymbol{x}}^{T}\left(\ddot{\boldsymbol{r}}_{2}-\ddot{\boldsymbol{c}}-2 \dot{x}_{2} \dot{\widehat{\boldsymbol{x}}}-x_{2} \ddot{\hat{\boldsymbol{x}}}-2 \dot{y}_{2} \dot{\hat{\boldsymbol{y}}}-y_{2} \ddot{\overrightarrow{\boldsymbol{y}}}\right) \\
& \ddot{y}_{2}=\widehat{\boldsymbol{y}}^{T}\left(\ddot{\boldsymbol{r}}_{2}-\ddot{\boldsymbol{c}}-2 \dot{x}_{2} \dot{\hat{\boldsymbol{x}}}-x_{2} \ddot{\ddot{\boldsymbol{x}}}-2 \dot{y}_{2} \dot{\hat{\boldsymbol{y}}}-y_{2} \ddot{\hat{\boldsymbol{y}}}\right)
\end{aligned}
$$

また，コンロッド大端部からコンロッド重心位置ま での長さを $L_{c}$ とすると, 要素座標系上でのコンロッ ド重心位置・速度・加速度はそれぞれ，

$$
\begin{array}{rr}
x_{3}=\frac{L_{c}}{L} x_{1}+\frac{L-L_{c}}{L} x_{2}, & y_{3}=\frac{L-L_{c}}{L} y_{2} \\
& \cdots \cdots \cdots \cdots \\
\dot{x}_{3}=\frac{L_{c}}{L} \dot{x}_{1}+\frac{L-L_{c}}{L} \dot{x}_{2}, & \dot{y}_{3}=\frac{L-L_{c}}{L} \dot{y}_{2} \\
& \ldots \ldots \cdots \cdots \\
\ddot{x}_{3}=\frac{L_{c}}{L} \ddot{x}_{1}+\frac{L-L_{c}}{L} \ddot{x}_{2}, & \ddot{y}_{3}=\frac{L-L_{c}}{L} \ddot{y}_{2}
\end{array}
$$

となる。一方, 全体座標系上でのコンロッド重心位 置・速度・加速度ベクトルは,

$$
\begin{aligned}
& \boldsymbol{r}_{3}=\boldsymbol{c}+x_{3} \widehat{\boldsymbol{x}}+y_{3} \widehat{\boldsymbol{y}} \\
& \dot{\boldsymbol{r}}_{3}=\dot{\boldsymbol{c}}+\dot{x}_{3} \hat{\boldsymbol{x}}+x_{3} \dot{\boldsymbol{x}}+\dot{y}_{3} \widehat{\boldsymbol{y}}+y_{3} \dot{\hat{\boldsymbol{y}}} \cdots \cdots \cdots(15 \cdot \mathrm{b}) \\
& \ddot{\boldsymbol{r}}_{3}=\ddot{\boldsymbol{c}}+\ddot{x}_{3} \hat{\boldsymbol{x}}+2 \dot{x}_{3} \dot{\boldsymbol{x}}+x_{3} \ddot{\boldsymbol{x}}+\ddot{y}_{3} \widehat{\boldsymbol{y}}+2 \dot{y_{3}} \dot{\hat{\boldsymbol{y}}}+y_{3} \ddot{\boldsymbol{y}}
\end{aligned}
$$

で得られる.また, 要素座標系上でのコンロッド摇動 角 $\phi_{l}$ は,

$$
\phi_{l}=\tan ^{-1}\left(\frac{y^{2}}{x_{1}-x_{2}}\right)
$$

で得られる。一方, 全体座標系上でのコンロッド摇動
角 $\phi$ は, 全体座標系に対する要素座標系のなす角(図 4 の $z$ 軸回りのボア傾斜角)を $\gamma$ とすると,

$$
\phi=\phi_{l}+\gamma
$$

で得られる。また，全体座標系に対する要素座標系の 角加速度（図 4 の $z$ 軸回り）を $\alpha$ とすると, 全体座標系 に扔けるコンロッド摇動角の加速度は,

$$
\ddot{\phi}=\ddot{\phi}_{l}+\alpha
$$

となる。

$3 \cdot 2$ 作用力の計算式 四 4 より，ピストンとコ ンロッドの並進運動に関する運動方程式は,

$$
m_{p} \ddot{\boldsymbol{r}}_{1}=\left(F_{f}+F_{c}+F_{1 x}\right) \widehat{\boldsymbol{x}}+\left(F_{s}+F_{1 y}\right) \hat{\boldsymbol{y}}
$$

$$
m_{c} \ddot{\boldsymbol{r}}_{3}=-\left(F_{1 x}+F_{2 x}\right) \hat{\boldsymbol{x}}-\left(F_{1 y}+F_{2 y}\right) \hat{\boldsymbol{y}} \cdots(19 \cdot \mathrm{b})
$$

となる。

コンロッドの重心回りの回転に関する運動方程式 は，コンロッド摇動角 $\phi$ の反時計回りを主として，

$$
\begin{gathered}
J_{c} \ddot{\phi}=-F_{1 x}\left(L-L_{c}\right) \sin \phi+F_{2 x} L_{c} \sin \phi \\
-F_{1 y}\left(L-L_{c}\right) \cos \phi+F_{2 y} L_{c} \cos \phi \quad \cdots
\end{gathered}
$$

となる.式(19)の両式を加え, 左から $\widehat{\boldsymbol{x}}^{T}, \widehat{\boldsymbol{y}}^{T}$ を掛け ると,クランクピン荷重 $F_{2 x}, F_{2 y}$ は

$$
\begin{aligned}
& F_{2 x}=-m_{p} \widehat{\boldsymbol{x}}^{T} \ddot{\boldsymbol{r}}_{1}-m_{c} \widehat{\boldsymbol{x}}^{T} \ddot{\boldsymbol{r}}_{3}+F_{f}+F_{c} \cdots(21 \cdot \mathrm{a}) \\
& F_{2 y}=-m_{p} \widehat{\boldsymbol{y}}^{T} \ddot{\boldsymbol{r}}_{1}-m_{c} \widehat{\boldsymbol{y}}^{T} \ddot{\boldsymbol{r}}_{3}+F_{s} \quad \cdots \cdots \cdots(21 \cdot \mathrm{b})
\end{aligned}
$$

となる。また，式(21)を式(19)に代入し，左から $\widehat{x}^{T}$, $\widehat{\boldsymbol{y}}^{T}$ を掛けると，ピストンピン荷重 $F_{1 x}, F_{1 y}$ は,

$$
\begin{aligned}
& F_{\perp x}=m_{p} \widehat{x}^{T} \ddot{\boldsymbol{r}}_{1}-F_{f}-F_{c} \\
& F_{1 y}=m_{p} \widehat{\boldsymbol{y}}^{T} \ddot{\boldsymbol{r}}_{1}-F_{s} \cdots \cdots
\end{aligned}
$$

となる、ここで, ピストン摩擦力 $F_{f}$ はピストン側压 力 $F_{s}$ を抗力として,

$$
F_{f}=-\mu\left|F_{s}\right| \operatorname{sgn}\left(\dot{x}_{1}\right)
$$

で計算する.式 $(21) 〜(23)$ を式 $(20)$ に代入して，ピス

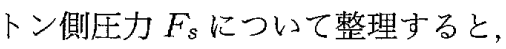

$$
\begin{aligned}
F_{s} & =\frac{1}{L\left[\cos \phi-\mu \sin \phi \operatorname{sgn}\left(\dot{x}_{1}\right)\right]}\left(m_{p} \widehat{\boldsymbol{x}}^{T} \ddot{\boldsymbol{r}}_{1} L \sin \phi\right. \\
& +m_{p} \widehat{\boldsymbol{y}}^{T} \ddot{\boldsymbol{r}}_{1} L \cos \phi+m_{c} \widehat{\boldsymbol{x}}^{T} \ddot{\boldsymbol{r}}_{3} L_{c} \sin \phi \\
& \left.+m_{c} \widehat{\boldsymbol{y}}^{T} \ddot{\boldsymbol{r}}_{3} L_{c} \cos \phi-F_{c} L \sin \phi+J_{c} \ddot{\phi}\right) \cdots(24)
\end{aligned}
$$

が得られる。燃焼ガスの爆発力 $F_{c}$ は式 $(2)$ を用い る.

以上より, 全体座標からみた要素座標系の位置・速 度・加速度べクトル $(\boldsymbol{c}, \dot{\boldsymbol{c}}, \ddot{\boldsymbol{c}})$ と要素座標系の姿樊 $(\hat{x}, \hat{y})$ が計算されると, 全体座標系上でのクランク ピン位置・速度 ・加速度ベクトル $\left(\boldsymbol{r}_{2}, \dot{\boldsymbol{r}}_{2}, \ddot{r}_{2}\right)$ を力 として, 各作用力が求まる.

\section{4. 新力要素の有効性検証}

$4 \cdot 1$ 計算モデル 直列 4 気筒エンジンを対象に, クランク軸のねじれ振動を計算し，新力要素の有効性 
を検証する。

図 5 にEVASモデルの概要, 表 1 に対象エンジン の諸元を示す．図 5 に示すように，クランク軸には円 環状のゴムとプーリで構成される振動低減用のダイナ ミックダンパが取り付けられている.

物体要素のクランク軸(クランクプーリやフライホ イールを含む)は 8224 要素で $2.5 \mathrm{kHz}$ までの固有モ ードを採用し，シリンダブロック系(ミッションケー スやオイルパンなどのケース系を含む) は約 79502 要 素で, $1.0 \mathrm{kHz}$ までの固有モードを採用する。また， シリンダブロック系は 4 つのマウント要素で支持し, クランク軸はモータ要素でトルクを吸収する。

計算におけるエンジンの回転数条件は $2000 \sim 6000$ $\mathrm{rpm}$ とし, 気筒内压力 $p_{c}$ は各回転数の全負荷運転条 件で実測した燃焼圧データを用いる．図6に 1 番気筒

Table 1 Specifications of engine

\begin{tabular}{|l|c|c|}
\hline Parameter & Value & Unit \\
\hline \hline Displacement & $1.497 \times 10^{-3}$ & $\mathrm{~m}^{3}$ \\
\hline Compression ratio & 8.0 & - \\
\hline Bore $: D$ & 0.075 & $\mathrm{~m}$ \\
\hline Stroke $: 2 R$ & 0.084 & $\mathrm{~m}$ \\
\hline Piston mass $: m_{p}$ & 0.327 & $\mathrm{~kg}$ \\
\hline Connecting-rod mass $: m_{c}$ & 0.362 & $\mathrm{~kg}$ \\
\hline Connecting-rod inertia $: J_{c}$ & $1.038 \times 10^{3}$ & $\mathrm{~kg} \cdot \mathrm{m}^{2}$ \\
\hline Connecting-rod length $: L$ & 0.141 & $\mathrm{~m}$ \\
\hline Bearing radius $: r$ & $23.0 \times 10^{-3}$ & $\mathrm{~m}$ \\
\hline Bearing width $: B$ & $22.0 \times 10^{-3}$ & $\mathrm{~m}$ \\
\hline Bearing clearance $: \bar{h}$ & $25.0 \times 10^{-6}$ & $\mathrm{~m}$ \\
\hline Oil viscosity $: \eta$ & $7.87 \times 10^{-3}$ & $\mathrm{~Pa} \cdot \mathrm{s}$ \\
\hline
\end{tabular}

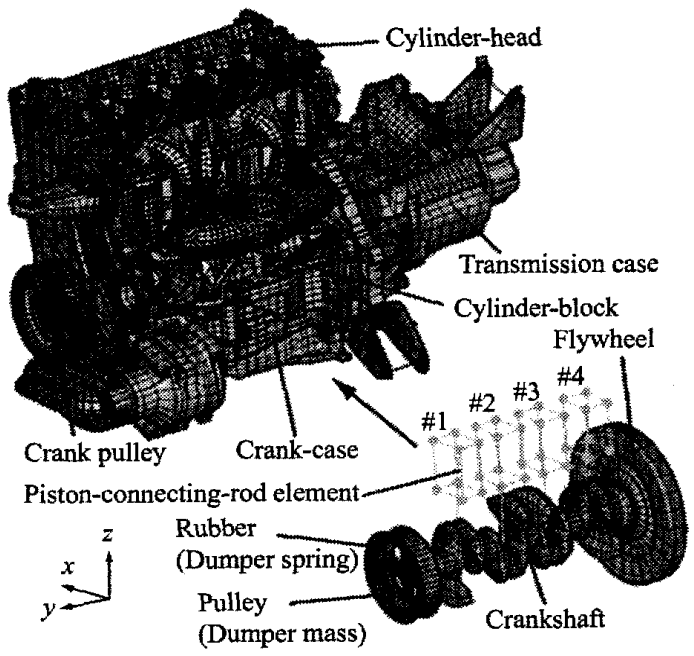

Fig. 5 Simulation model in EVAS
における代表的な燃焼圧データの時刻歴を示す．気筒 爆発は，1 番，3番，4番，2番気筒の順で繰り返され る.

なお，新力要素との比較のため, ピストンとコンロ ッドを物体要素でモデル化した場合の計算も行なう (以下,フルモデルとよぶ)。この場合はピストンとボ ア(シリンダブロック)の間, ピストンとコンロッドの 間，コンロッドとクランクピンの間は，ばね・ダンパ 要素で結合する。

$4 \cdot 2$ 計算結果 このエンジンで比較的大きな共 振が発生する回転 6 次成分のクランク軸ねじれ振動に 着目する.クランク軸先端のねじれ振動変位の計算結 果と実験結果を図 7 に示す。実験では，低速側(3000 $\mathrm{rpm}$ 付近)と高速側 (5 $500 \mathrm{rpm}$ 付近)に2つの共振ピ ークが存在する。前報の力要素を用いた計算では，低

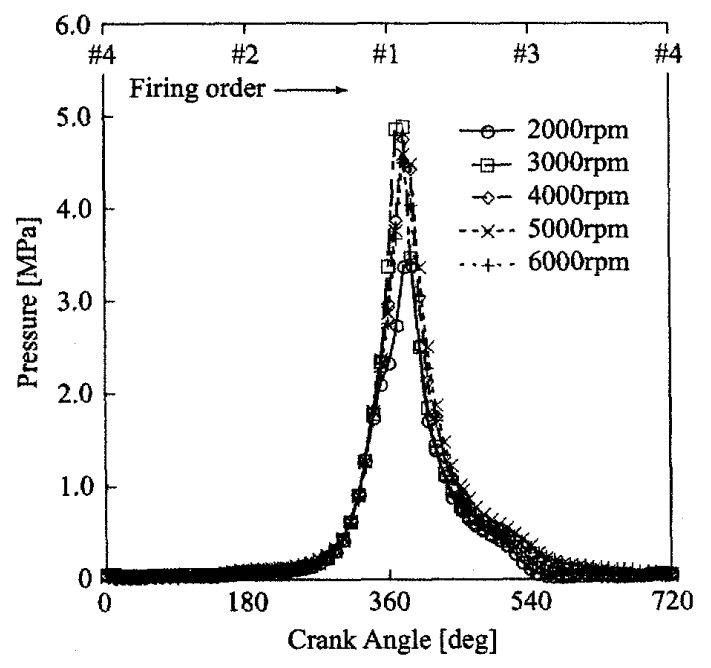

Fig. 6 Combustion pressure in 1st cylinder

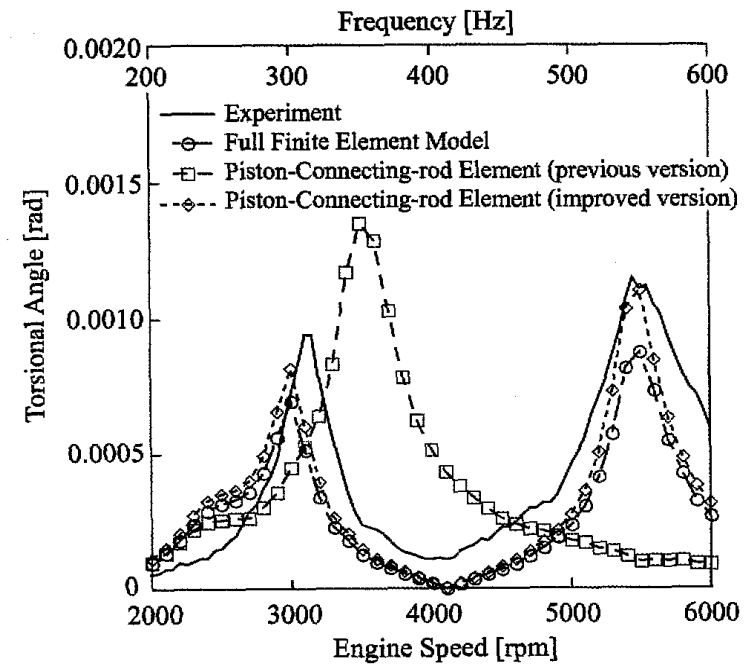

Fig. 7 Torsional vibration of crank pulley (6th rotating order) 
速側の共振点が $500 \mathrm{rpm}$ ほど高くなり(高速側の共振 点は $6000 \mathrm{rpm}$ より高速側にずれる)，振幅の誤差も 大きい.

これに対して, 本報で提案する新力要素を用いると， $2 つ の$ 共振点とその振幅ともに，ほほ笑験と対応する 結果が得られ, 旧力要素に対して大幅に計算精度が改 善できていることが分かる.なお，ピストン・コンロ ッド系とクランク軸の連成を考慮した新力要素では, 旧力要素と比較して共振周波数も共振レベルも下がっ ていることから，ピストン・コンロッド系は，クラン ク軸のねじれ振動の等価慣性を増す作用をしていると 考えられる。

また，図 7 に示すように, 新力要素の計算結果は, フルモデルのそれともほぼ対応する.フルモデルで は, ピストンとコンロッドを物体要素でモデル化して, それらはクランク軸やシリンダブロックとばね結合し ているため, ピストン・コンロッド系とクランク軸の 動的な相互作用が正確に表現でき，ピストン・コンロ ッド系に発生する力を正確に計算できていると考えら れる。

なお，計算時間の点では，フルモデルは各回転数で 数時間を要するのに対し，新力要素を用いると，物体 要素数が少なく，全体の計算自由度が大幅に減るため, 計算時間は数分(フルモデルの 100 分の 1 以下)に短縮 される。また，新力要素の計算時間は旧力要素と同程 度である。したがって，高精度と計算時間短縮を両立 するという点では，新方要素を用いる手法が最も実用 的である。

\section{5. クランク軸とシリンダブロックの} 連成振動解析

新力要素を用いた現象解明の一例として, 表 2 に示 すクランク軸の剛性を 3 種類変化させた場合につい て,クランク軸の振動がシリンダブロックの共振現象 に及ぼす影響を調べ，回転系のクランク軸と静止系の シリンダブロックとの連成振動メカニズムを考察す 万.

ここでは, シリンダブロックの中で比較的大きな共

Table 2 Parameters of crankshaft

\begin{tabular}{|c|c|c|c|}
\hline Case & Material & $\begin{array}{c}\text { Crankpin } \\
\text { diameter [m] }\end{array}$ & $\begin{array}{c}\text { Bending } \\
\text { rigidity ratio }\end{array}$ \\
\hline \hline 1 & steel & $40.0 \times 10^{-3}$ & 1.0 \\
\hline 2 & cast iron & $40.0 \times 10^{-3}$ & 0.85 \\
\hline 3 & cast iron & $38.0 \times 10^{-3}$ & 0.77 \\
\hline
\end{tabular}

振現象が発生するスカート部の回転 7 次成分の振動に 着目する. 図 8 にその計算結果と対応する実験結果を 示す.エンジン回転数 $3000,4000,5000 \mathrm{rpm}$ 付近に 3つの共振が発生し, タランク軸の剛性が高いほど, 各共振点が上昇し，共振レベルが下がる。

これらの共振現象の発生メカニズムを考察するた め,シリンダブロックの主要な振動起振力である主軸 受の伝達荷重に着目する。図 9 に 4 番軸受のエンジン 水平方向の伝達荷重(回転 7 次成分)を示す，図 8 kほ ぼ対応するエンジン回転数で, 軸受の伝達荷重にも大 きなピークが見られる.このことから，シリンダブロ ックの共振現象には, 4 番軸受の伝達荷重の增大が関 与していると考えられる.

次に，この 4 番軸受の伝達荷重の増大に関与するク ランク軸の权じれ振動を調べる。図 10 にクランク軸

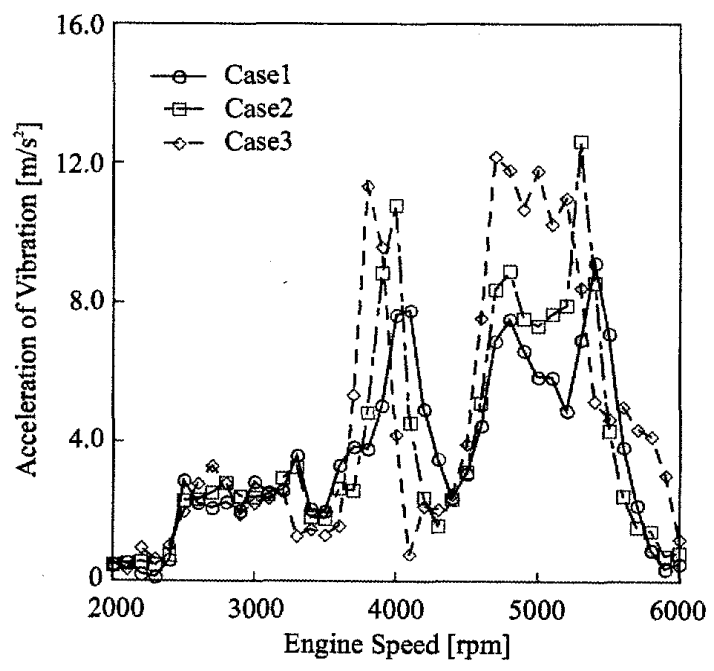

(a) Calculation result

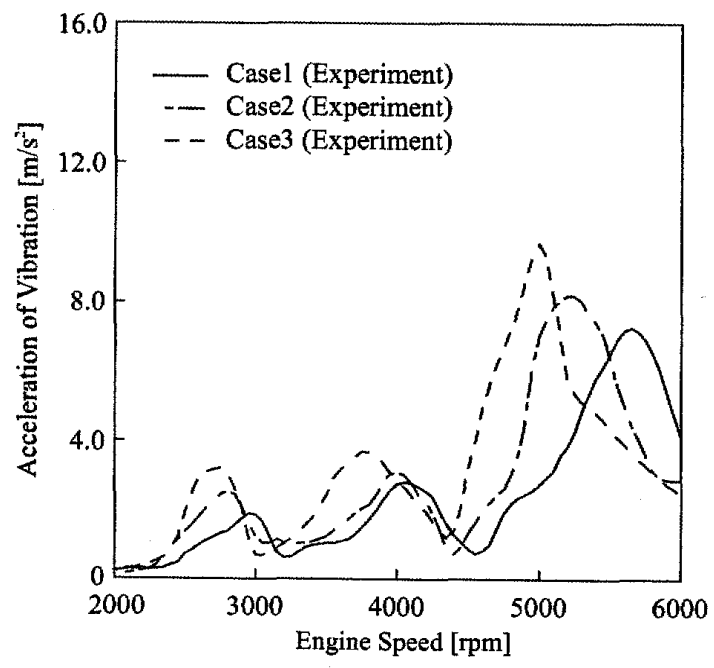

(b) Experimental data

Fig. 8 Vibration of cylinder-block (7th rotating order) 


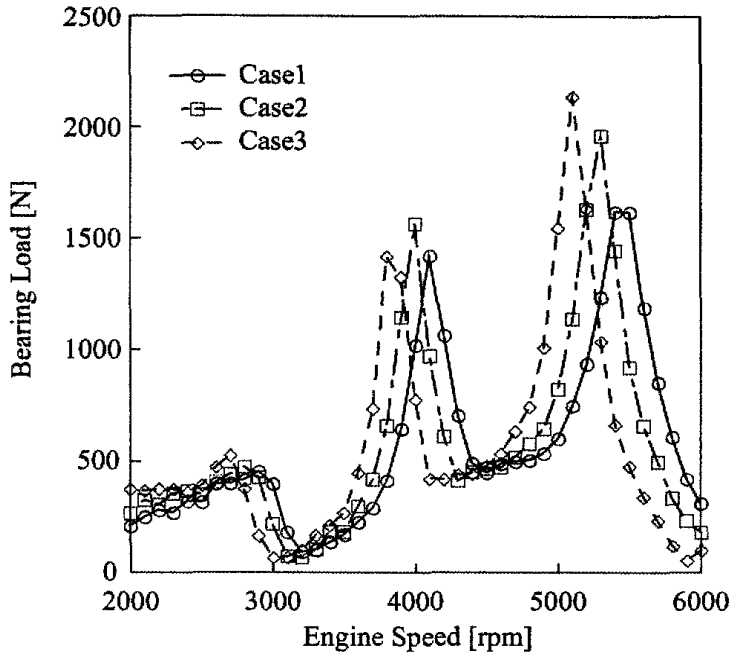

Fig. 9 Bearing load at 4 th journal bearing ( 7 th rotating order)

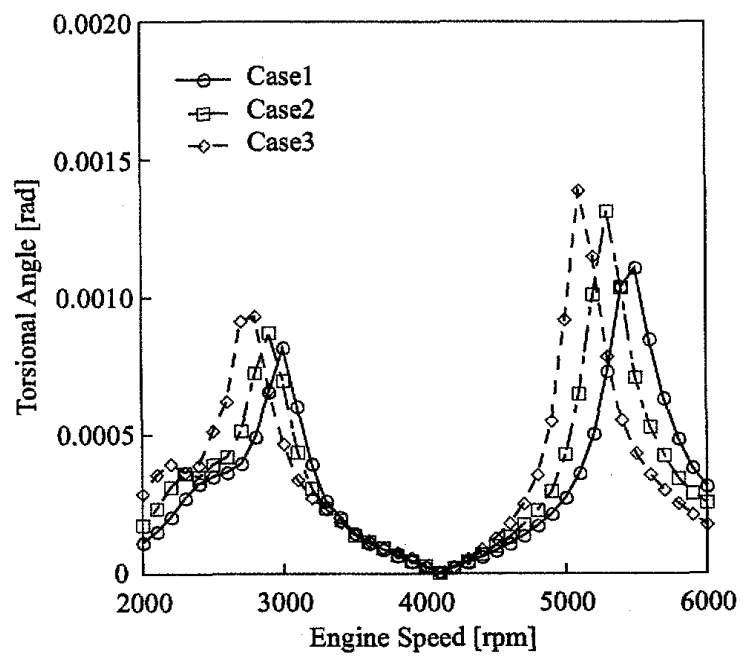

(a) Calculation result

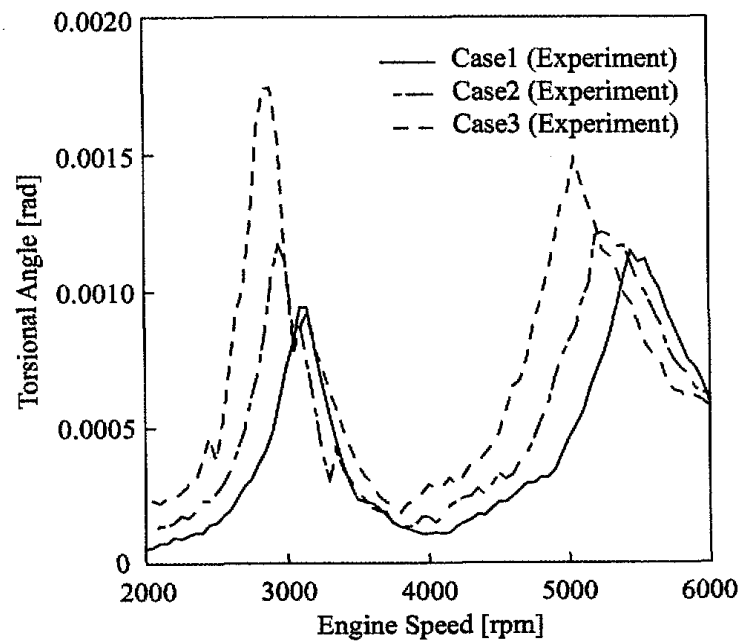

(b) Experimental data

Fig. 10 Torsional vibration of crank pulley (6th rotating order)
のねじれ振動について回転6 次成分の計算結果と,そ れに対応する実験結果を示す。これらのクランク軸の ねじれ振動の共振特性が, 図 9 の軸受荷重のそれと対 応することから, $3000 \mathrm{rpm}$ 付近と $5000 \mathrm{rpm}$ 付近の 軸受荷重の増大は, クランク軸の秝じれ振動の共振に 起因していると考えられる.

ここで, $5000 \mathrm{rpm}$ 付近の共振に関して, クランク 軸の振動モードを調べる. 図 11 に,クランク軸とと もに回転する座標系から見た回転 6 次成分のモード変 形図を示す。図 11 上に示すように，この周波数では， クランク軸全体が大きくねじれ変形を起こし, 図 11 下に示すように, 4 番軸受部の変位が最大となるクラ ンク軸の曲げ変形を伴うことが分かる．このような回 転座標系上の回転 6 次のクランク軸の曲げ振動は，静 止座標系のシリンダブロックへ伝達される際には，回 転次数土 1 次分の周波数変換によって, 回転 5 次と回 転 7 次成分の振動として伝わる。したがって，図 9 の 軸受荷重の $5000 \mathrm{rpm}$ 付近の共振ピークは, クランク 軸の回転 6 次のねじれ・曲げ連成振動によって, 静止 座標系の軸受内に回転 7 次の軸振動が発生し, それに 伴って, 軸受油膜の伝達荷重が増大したことに起因す ると考えられる。

同様に，図 9 の軸受荷重の $4000 \mathrm{rpm}$ 付近の共振ピ ークは, 図 12 に示すクランク軸の回転 8 次の秝じ

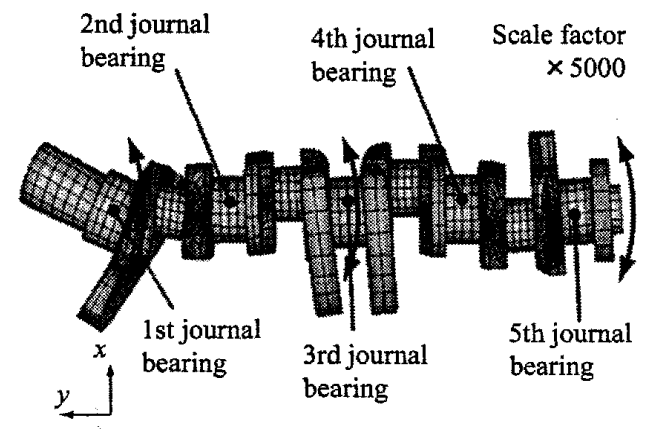

(a) Deformation mode of crankshaft

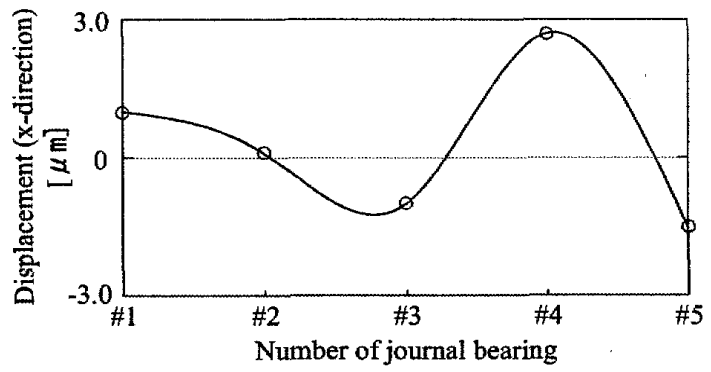

(b) Displacement of each journal bearing

Fig. 11 Deformation mode of crankshaft (Case 3, 5100 rpm, 6th rotating order) 


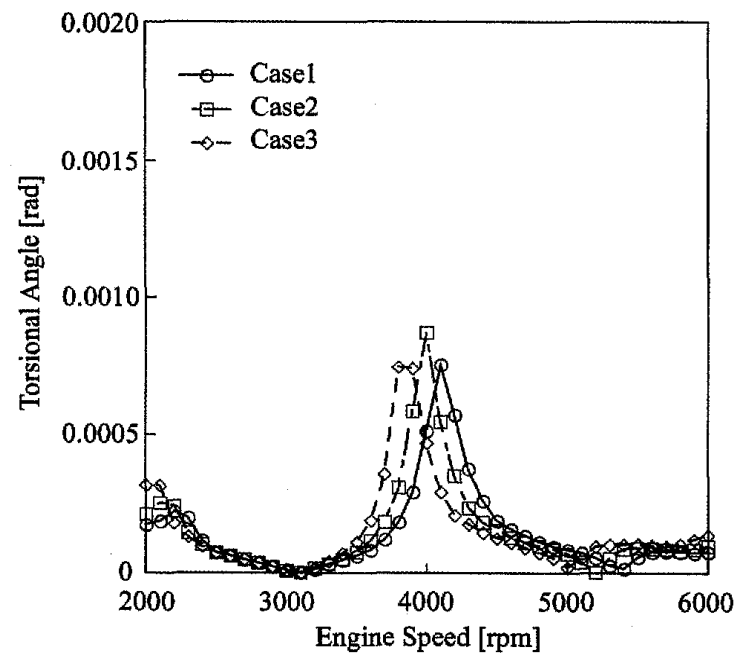

Fig. 12 Torsional vibration of crank pulley (8th rotating order)

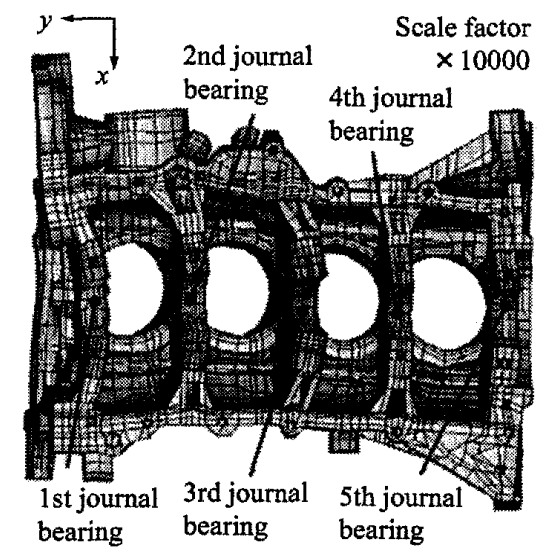

Fig. 13 Elastic vibration mode of cylinder block (Case 3, $5100 \mathrm{rpm}$, 7th rotating order)

れ・曲げ連成振動に起因すると考えられる。そして最 終的には，この回転 7 次成分の軸受荷重が, 図 13 に示 すシリンダブロックの曲げ変形モードを励起し, シリ ンダブロックの共振現象として観測される。

以上のことから，この場合のクランク軸からシリン ダブロックへの振動伝達メカニズムは, 図 14 のよう にまとめられる。トルク変動によるクランク軸のねじ れ・曲げ連成振動が主蟿受部の荷重変動を励起し, シ リンダブロックの振動の増大を引き起こす。そしてシ リンダブロック振動が車室内騒音につながると考えら れる。また, クランク軸剛性を変化させた場合の結果 から, クランク軸の高剛性化が, そのねじれ・曲げ連 成振動を低減し, 最終的にシリンダブロックの共振周 波数を高め, 振動レベルの低減にも有效であることが わかった。

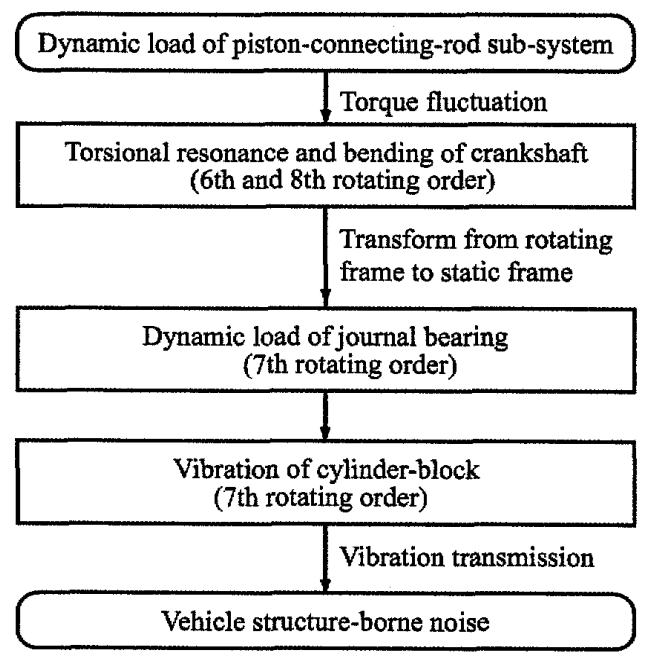

Fig. 14 Vibration transmission from piston-connecting-rod to cylinder block

\section{6. 結言}

クランク軸のねじれ振動を高速・高精度に計算する ために,クランク軸とピストン・コンロッド系の動的 な相互作用を考慮できるピストン・コンロッド系の力 要素を提案し, その有効性を実験結果で検証した。ま た，その力要素を用いて，クランク軸のねじれ・曲げ 連成振動からシリンダブロックへの振動伝達メカニズ ムを解明し，以下の知見を得た。

（1）ピストンとコンロッドの運動方程式と幾何学 的拘束条件から,クランクピン位置・速度・加速度を 入力としてピストン・コンロッド系のジョイント部に 発生する作用力を計算する新力要素を定式化した.こ れにより, クランク軸の弾性変形に起因する回転半径 とクランク軸の変動を考慮した各気筒の作用力の計算 が可能になり,クランク軸とピストン・コンロッド系 の動的な連成効果を含めて，エンジン全体系の振動計 算ができる。

（2）新力要素では, クランク軸のねじれ振動を考 慮したピストン・コンロッド系の動的相互作用が考慮 可能であり, 旧力要素では表現できなかったクランク 軸礼じれ振動の共振周波数や共振レベルを実験値と同 程度まで低下させる。また, 新力要素を用いるとフル モデルと同精度でこの効果を正しく表現でき, フルモ デルより高速に計算することができる.

（3）クランク軸のねじれ共振は曲げ振動を伴うこ とにより, 主軸受荷重を増大し, シリンダブロックの 共振現象を引き起こす。この場合, 回転系から静止系 への回転次数比変換により, 例皃ば,クランク軸の回 転 6 次振動は, シリンダブロックの回転 7 次振動とし 
て観測される。なおこのメカニズムで発生するシリ ンダブロックの共振は, クランク軸の高剛性化により 低減することができる.

\section{謝辞}

本研究の実施にあたり，トヨ夕自動車(株)エンジン プロジェクト推進部第 2 機能設計室の方々にご協力と ご助言を頂いたことを記し，深く感謝する。

\section{文献}

(1) Morita, T. and Okamura, H., Three-Dimensional Vibration Analysis of Crankshaft System under Firing Conditions, Transactions of the Japan Society of Mechanical Engineers, Series C, Vol.60, No. 574 (1994), pp. 1909-1916.

(2) Naganuma, T., Okamura, H. and Sogabe, K., Influence of the Cylinder Block Dynamic Stiffness and the Crankshaft Damper Characteristics on the ThreeDimensional Vibrations of the Crankshaft-Sysmtems, Transactions of the Japan Society of Mechanical Engineers, Series C, Vol.64, No.622 (1998), pp. 1904-1911.

( 3 ) Kobayashi, Y., Katsu, M., Kondo, M., Fujimoto, H. and Aoyama, S., Time-marching Analysis of Crankshaft and Cylinder Block Behavior Coupled through Main Bearing Lubrication, The 11th Internal Combustion Engine Synposium, (1993-7), pp. 369-374.

(4) Harui, N. and Nakada, T., Nonliner Vibration Analysis for a Rotating Crankshaft, IMechE, (1994), pp. 199209.

(5) Aoyama, T., Inagaki, M., Kawamoto, A., Mori, N., Ikeura, $\mathrm{O}$. and Yamamoto, K., Analysis of main bear- ing force and cylinder block vibration related to engine air borne noise, Review of the Society of Automotive Engineers of Japan, Vol. 21, No. 33 (2000), pp. 404-406.

(6) Tsukahara, H., Takeuchi, Y. and Sato, M., Development of prediction method for powerunit vibration induced by crankshaft vibration, Proceedings of the Society of Automotive Engineers of Japan, 971 (19975), pp. 93-96.

(7) Sakai, T. and Iwahara, M., The Optimum Design of Engine Mounting for Heavy Duty Vehicle, Transactions of the Japan Society of Mechanical Engineers, Series C, Vol. 65, No. 631 (1999), pp. 887-894.

(8) Kawamoto, A., Inagaki, M., Aoyama, T., Mori, N. and Yasuda, K., Vibration of Moving Flexible Bodies, Transactions of the Japan Society of Mechanical Engineers, Series C, Vol. 65, No. 632 (1999), pp. 1331-1338.

(9) Kawamoto, A., Inagaki, M., Aoyama, T., Mori, N. and Yasuda, K., Vibration of Moving Flexible Bodies, Proc. DETC '99, (1999-9), DETC 99/VIB-8232.

(10) Kawamoto, A., Inagaki, M., Aoyama, T. and Mori, N., Prediction of Structural and Kinematic Coupled Vibration on Internal Combustion Engine, Transactions of the Japan Society of Mechanical Engineers, Series C, Vol. 67, No. 663 (2001), pp. 3428-3436.

(11) Kawaguchi, A., Kawamoto, A. and Aoyama, T., Flexible Multibody Analysis of Internal Conbustion

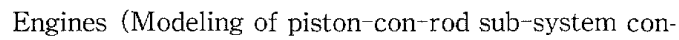
sidering kinematic feedback induced by torsional vibration of crankshaft), Proc. ACMD 2006, (2006-8), AT- $1 / 722$.

(12) Kawamoto, A., Krenk, S., Suzuki, A. and Inagaki, M., Flexible body dynamics in a local frame with explicitly predicted motion, International Journal for Numerical Methods in Engineering, (2009), (on-line available). 